\title{
DOKTRIN TENTANG SURGA: RELEVANSINYA BAGI TUGAS MISI SEDUNIA
}

\author{
Daniel Ronda \\ Sekolah Tinggi Theologia Jaffray \\ daniel.ronda@sttjaffray.ac.id
}

\begin{abstract}
Abstrak
Pentingnya doktrin tentang surga bagi orang percaya ditujukan secara jelas dalam artikel ini. Surga didefinisikan sebagai rumah atau tempat, bukan keadaan pikiran sebagaimana banyak sarjana dituntun untuk percaya. Kemudian sebagai tempat, surga menggambarkan sebagai tempat tinggal Yesus, dan tempat yang indah untuk semua orang percaya di mana kita benar-benar menjadi seperti Kristus dan menikmati hadirat Allah. Selanjutnya, kegiatan orang-orang kudus di surga dijelaskan. Neraka ini juga disebutkan secara singkat dalam artikel ini sebagai kontras dengan surga. Sebagai kesimpulan surga harus menjadi faktor pendorong bagi orang percaya hari ini untuk mencapai misi kita untuk dunia sebagai pengikut Yesus.

Kata-kata kunci: surga, Yesus, misi, dunia, neraka

This article carefully addresses the importance of the doctrine of heaven to believers. Heaven is defined as a home or a place, and not a state of mind, as many scholars believe it to be. As a place, heaven is described as Jesus' dwelling place; a beautiful place for all believers where they become fully like Christ and enjoy the presence of God. Additionally, this article explains the activities of the saints in heaven. Hell is mentioned briefly as well, as a contrast to heaven. Thus, this article concludes that heaven should be a motivating factor for believers today to accomplish their mission in the world as Jesus' followers.
\end{abstract}

Keywords: heaven, Jesus, mission, world, hell

\section{Pendahuluan}

\section{"Thinking of Home"}

Sewaktu saya berusia 13 tahun ada peristiwa yang tidak dapat saya lupakan yaitu berdoa tentang surga. Waktu itu untuk pertama kalinya saya mengikuti retret remaja yang diadakan gereja di sebuah panti asuhan di Klungkung Bali. Malam itu, setelah seluruh acara 
selesai, kami berdoa dalam kelompok pada malam hari. Saya mengingat persis ada seorang gembala dari Sumbawa Besar, yang adalah mentor kami di tempat retret memimpin untuk doa tidur. Di bagian akhir doanya dia berdoa seperti ini: "Ya Tuhan seandainya Engkau datang malam ini, kami siap bertemu dengan Engkau di surga. Namun seandainya Engkau belum datang malam ini, kami boleh bangun dan melayani Engkau besok harinya." Setelah doa itu, saya tidak dapat tidur memikirkan tentang doa itu, bagaimana jika Dia datang malam itu? Dengan cara apa kami akan ke surga? Dan seperti apakah surga itu? Ingatan akan doa itu sungguh melekat di hati saya sampai hari ini. Doa mentor di tempat retret telah mengubahkan pemahaman hidup saya sebagai orang percaya yang menjadikan surga sebagai motif hidup dan melayani. Saya harus memikirkan rumah di surga walaupun masih di dunia ini. Pengalaman seperti ini membuat kita sudah mulai menikmati surga bersama dengan Yesus.

Begitu pula ketika saya masuk sekolah teologi. Ketika saya belajar tentang misi dari para tokoh misi sering kita mendengar dalil bahwa Yesus segera datang seharusnya menjadi motif kita mengabarkan Injil. Motif seperti ini sangat menggairahkan sekali, karena kedatangan-Nya segera menyebabkan percepatan pekabaran Injil yang tiada taranya. Sebagai contoh bagaimana Dr. R. A. Jaffray melakukan tugas misi di mana pergerakan pekabaran Injil sejak dia mulai datang tahun 1928 di Indonesia telah dapat menaklukkan wilayah pelayanan yang begitu luas dari Sumatera sampai Papua. Walaupun dengan transportasi yang sederhana, sebelum Perang Dunia II tahun 1945 Jaffray sudah menyebarkan Injil ke seluruh Indonesia dalam kurun waktu 15 tahunan. ${ }^{1}$ Sebuah fenomena yang luar biasa dan tidak dapat ditandingi oleh para penerusnya sampai kini. Motif surga menjadikan pelaksanaan misi sangat efektif dan mungkin menjadi pertanyaan apakah hal ini masih ada dalam tugas penginjilan.

Terlepas dari dua cerita pengalaman di atas, pengajaran tentang surga perlu mendapatkan tempat dalam kehidupan gereja. Khusus dalam pembahasan tulisan ini dibahas tentang mengapa surga itu penting untuk diajarkan. Lalu dilanjutkan kepada penjelasan tentang apa dan bagaimana itu surga berdasarkan kajian teologis biblika dengan mengacu juga pada Yohanes 14:1-3 dan referensi lainnya termasuk kitab Wahyu. Pada akhirnya akan dibahas implikasi surga bagi umat Allah yang masih ada di dunia ini. Motif surga harus

\footnotetext{
${ }^{1}$ Kisah lengkapnya dapat dibaca di Rodger Lewis, Karya Kristus di Indonesia (Bandung: Kalam Hidup, 1995).
} 
menjadi pencetus dan penggerak untuk pelayanan kepada Tuhan yang lebih hebat lagi.

\section{Surga itu Penting}

Secara umum sebagian besar manusia percaya akan keberadaan surga atau kehidupan setelah kematian. Bahkan dalam film-film tentang surga sangat populer dan banyak dibuat termasuk oleh industri film Hollywood. Ini membuktikan bahwa di hati mereka percaya adanya surga. Tetapi penggambaran surga harus diakui lebih banyak menyimpang daripada gambaran yang sebenarnya tentang surga. Bahkan buku-buku teologi Kristen pun kurang banyak membahas tentang surga. Sebagai contoh, buku teologi reformed yaitu Teologi Sistematika oleh Louis Berkhof yang sebanyak 784 halaman itu hanya berisi penjelasan 1 halaman saja tentang surga. Memang sedikit sekali. Boleh dikatakan tulisan tentang surga tidak banyak. Tentu kita berutang pengajaran yang benar akan surga ini.

\section{Mengapa Pengajaran Surga Kurang Diperhatikan?}

Ada beberapa sebab mengapa pengajaran surga kurang menarik minat untuk dibahas sekalipun tidak disangkali hakikatnya. ${ }^{2}$

Pertama, kita hidup di dunia realitas visual dan pengalaman. Dalam dunia modern ini yang menawarkan visualisasi untuk dipercayai, maka yang lebih diterima menjadi keyakinan adalah apa yang terlihat, dialami dan yang disebut kenyataan. Sedangkan surga, walaupun telah diupayakan untuk memvisualkannya lewat film atau buku kesaksian, tetapi masih tetap dianggap sebagai sesuatu yang abstrak dan konsep saja. Kedua, kita hidup dalam kenyamanan dan kesenangan. Materialisme telah mewabah di mana-mana dan masuk ke dalam dunia gereja. Tidak sedikit pengajar materialisme yang menggambarkan surga itu sudah dapat dinikmati sekarang. Mereka telah berubah pandangan bahwa seharusnya orang merindukan surga yang ada di dunia ini sebagaimana perjuangan kaum hedonis. Jadi pembahasan surga itu tidak perlu dibahas, tetapi lebih penting menghadirkan "surga" di dunia ini dengan kesenangan, kenikmatan dan keindahan fisik materi. Topik surga setelah kematian tidak terlalu mendapatkan pembahasan yang memadai karena perubahan konsep surga di dunia ini. Ketiga, surga otomatis akan dialami dan diterima setelah kematian seseorang. Sebagaimana tidak ada yang bisa

\footnotetext{
${ }^{2}$ Bahasan diangkat dari isu yang dibahas oleh Edward Donelly, Biblical Teaching on the Doctrines of Heaven and Hell (Edinburgh, UK: Banner of Truth Trust, 2005), 6567.
} 
menghindari kematian, maka tidak ada yang dapat menghindari untuk masuk surga. Karena ini secara otomatis terjadi maka seharusnya tidak perlu buang waktu membahas surga. Keempat, ada anggapan bahwa surga bukan lokasi dan aktivitas yang menarik. Memang digambarkan keindahannya, tetapi sulit menyatakan keindahan untuk ditinggali. Tidak ada pernak-pernik yang indah yang bisa membayangkan surga itu menarik untuk dibahas. Jika digambarkan bahwa surga penuh dengan permata dan emas, maka itu visualisasi yang terlihat dalam kitab Wahyu. Memang indah, tapi kaum skeptis berpikir apakah tidak membosankan kalau tiap hari menyaksikan emas? Cara berpikir ini semakin menyulitkan menjelaskan keindahan surga yang tiada taranya. Apalagi ada salah konsepsi tentang surga bahwa itu bukan sesuatu yang menarik. Bila digambarkan bahwa umat Allah dan segala makhluk surga memuji Tuhan dan menyembah Dia, lagi-lagi kaum skeptis berpikir apakah itu tidak membosankan? Inilah yang dianggap tidak ada pernakpernik keindahan sebuah kehidupan surga dan hanya monoton. Kelima, banyak orang Kristen merasa pembahasan tentang surga itu tidak relevan lagi. Memang penjelasan kosmologi kitab Wahyu tentang surga memakai ekspresi bahasa 2000 tahun yang lalu, sehingga kelihatan kuno dan berdimensi masa lalu. Visualisasi lewat gambar yang memperlihatkan surga seperti tempat kuno yang tidak relevan sehingga banyak orang Kristen pun akhirnya juga tidak tertarik dengan konsep surga. Keenam, konsep surga yang digambarkan dalam kitab Wahyu begitu kompleks sehingga banyak sekali penafsiran yang membingungkan umat Allah. Ada yang fokus kepada penafsiran harfiah dan ada yang begitu menyederhanakan konsep eskatologi di mana mereka beranggapan bahwa kitab Wahyu adalah sastra apokaliptik semata yang bertujuan sebagai penghiburan umat Tuhan yang menderita karena aniaya. Jadi tidak dianggap sebagai suatu yang perlu ditafsirkan tetapi hanya simbol kemenangan di mana Tuhan akan berhasil mengalahkan iblis dan kejahatannya termasuk jemaat yang menganiaya mereka akan dikalahkan. Perbedaan ini membuat kebingungan sehingga banyak yang mengabaikan pengajaran surga ini. Keterbatasan cara berpikir kita membuat kita menyerah dalam membahas surga.

\section{Pentingnya Doktrin Tentang Surga}

Surga tidak sesederhana yang kita pikirkan, itulah sebabnya perlu ada pengajaran yang memadai akan hal ini. Ada beberapa hal penting tentang pengajaran surga: ${ }^{3}$

\footnotetext{
${ }^{3}$ Diambil dari pembahasan Donelly, 67-69.
} 
Pertama, tidak otomatis seseorang masuk surga setelah kematian. Kematian bukan visa langsung ke surga, karena ada dua tempat yaitu neraka juga (tentu memerlukan pembahasan tersendiri). Mereka harus melewati iman di dalam Yesus Kristus. Di dalam kitab Wahyu jelas bahwa disebutkan pesta anak Domba Allah dalam Wahyu 5, sehingga Kristus adalah pusat aktivitas surga itu sendiri. Kedua, ketika ada banyak pengajaran yang keliru, maka kita berutang memberikan penjelasan yang benar tentang surga dan teknik penafsiran kitab Wahyu secara benar. Hal ini membuat jemaat tidak akan mudah diombang-ambingkan dengan teknik penafsiran dangkal yang mencari figur Antikristus di dunia ini dan menyalahkan berbagai sistem moneter dan finansial karena ketidakpahaman terhadap kitab Wahyu. Ketiga, motif misi yang utama adalah surga dan neraka. Melaksanakan misi tidak dapat dipisahkan dari tujuan utama yaitu membawa seseorang memiliki kepastian tentang surga. Tanpa motif surga, misi tidak lebih dari sebuah upaya penyelamatan yang dilakukan oleh lembaga-lembaga atau yayasan-yayasan kemanusiaan.

\section{Seperti Apa Surga itu?}

Kata surga sendiri berasal dari kata shamayim (Ibrani) atau ouranos (Yunani). Kata ini bisa menunjuk kepada langit. Misalnya, pada mulanya Allah menciptakan langit dan bumi. Ada juga makna lain tentang surga, di mana digambarkan sebagai Tuhan. Misalnya ucapan anak bungsu yang hilang yang mengatakan bahwa ia telah berdosa terhadap bapanya dan surga (Luk. 15:18, 21). Namun yang dimaksudkan surga dalam pembahasan ini adalah tempat Tuhan bersemayam. Di surga, Tuhan dan orang percaya akan bersama-sama dalam kekekalan. ${ }^{4}$

Konsep surga merupakan ciri kekristenan dan agama-agama yang bernenek moyang Abraham (Yahudi, Kristen dan Islam). Sedang di dalam Hindu dan Buddha konsep penyatuan dengan sang pencipta yaitu universalisme menuju kepada anihilisme. Konsep ini sudah masuk juga dalam cara berpikir sebagian masyarakat Kristen di Barat, di mana penyatuan ini menghilangkan konsep manusia sadar di surga. Jadi surga tidak lebih dianggap sebagai sebuah gerakan psikologis keagamaan. Tak heran ada yang skeptis dan menyerang konsep surga sebagai sebuah pelarian. Karl Marx pernah mengungkapkan apa yang sudah populer pada waktu itu dengan pernyataan bahwa agama adalah candu masyarakat. Dan surga adalah bentuk tertinggi dari candu itu. Ada juga yang menyebut surga sebagai suatu bentuk untuk

\footnotetext{
${ }^{4}$ Millard J. Erickson, Christian Theology (USA: Baker, 1995), 1226-1227.
} 
menakut-nakuti pengikutnya supaya bisa lebih taat. Ini semacam kegiatan politik agama untuk membuat pengikutnya takut dalam berbuat salah dan lebih memiliki etika moral. Serangan seperti ini semakin membuat orang tidak memercayai eksistensi surga dan neraka.

Bahkan tidak sedikit dari teolog Kristen sendiri mulai meragukan keberadaan surga yang digambarkan oleh kitab Wahyu. Memang di dalam kitab Wahyu, surga adalah kota Allah, negara, kerajaan Allah dan Firdaus. Surga digambarkan memiliki dinding, berlantai emas, takhta, permata yang berharga, di mana ada pujian yang dinyanyikan oleh paduan suara dan malaikat. Gambaran tentang neraka pun digambarkan sebagai tempat penghukuman dan kengerian yang tiada taranya. Semua gambaran Wahyu di atas ini dianggap tidak lebih dari sebuah sastra politik agama yang membuat manusia tunduk kepada sistem sosial agama itu sendiri. Benarkah demikian? Tentu penggambaran surga seperti itu tidak dapat diterima dalam konteks teologi dan kemanusiaan itu sendiri, karena ketika manusia secara universal memercayai ada kehidupan setelah kematian, maka dapat dipastikan itu adalah hati nurani yang Tuhan taruh dalam kehidupan manusia. Maka, bila memang surga adalah nyata, seperti apakah surga itu?

\section{Surga itu "Rumah"}

Saya sangat senang akan penggambaran surga itu seperti rumah. ${ }^{5}$ Yesus menggambarkan kepergian-Nya ke surga untuk menyediakan tempat atau rumah bagi kita. ${ }^{6}$

Manusia pada dasarnya diciptakan di taman Eden yang adalah rumah mereka. Akibat dosa, Adam dan Hawa kehilangan rumah mereka. Mereka terusir dan menjadi pengembara di bumi ini. Setiap kali kita melihat dosa dalam Perjanjian Lama, maka si pelaku dibuat mengembara dan kehilangan rumah dan tempat tinggalnya. Kisah Abraham menjadi momen menjanjikan setelah kejahatan manusia yang begitu besar. Abraham dikeluarkan dari rumah orang tuanya dan dibawa ke tempat yang baru. Rumah di mana Abraham berada penuh

\footnotetext{
${ }^{5}$ James Montgomery Boice, Dasar-Dasar Iman Kristen (Jakarta: Penerbit Momentum, 2011), 827.

${ }^{6}$ Dalam Yohanes 14:1-3 digambarkan hal itu: "Janganlah gelisah hatimu; percayalah kepada Allah, percayalah juga kepada-Ku. Di rumah Bapa-Ku banyak tempat tinggal. Jika tidak demikian, tentu Aku mengatakannya kepadamu. Sebab Aku pergi ke situ untuk menyediakan tempat bagimu. Dan apabila Aku telah pergi ke situ dan telah menyediakan tempat bagimu, Aku akan datang kembali dan membawa kamu ke tempat-Ku, supaya di tempat di mana Aku berada, kamu pun berada."
} 
dengan berhala dan sekarang dibawa ke negeri perjanjian Allah. Kelihatannya bangsa Israel telah mendapatkan rumahnya yaitu Kanaan.

Tetapi beberapa abad kemudian, bangsa Israel kembali memberontak kepada Allah dan menyebabkan mereka harus mengembara lagi dan menjadi tawanan di negeri orang. Rumah mereka sebagai bangsa dihancurkan. Ketika mereka bertobat, mereka dikembalikan dari tawanan ke rumah mereka. Tetapi ketika terjadi lagi pemberontakan lagi kepada Allah, bangsa Israel diserakkan sampai ke seluruh dunia. Pada zaman Kristus, jemaat Tuhan sebagai Israel rohani mendapat janji rumah itu lewat karya penyelamatan Kristus. Karya Kristus datang untuk mengembalikan janji rumah itu kepada orang percaya dan kita menantikan hari, ketika semua kembali ke rumah Tuhan.

Bagaimana menggambarkan surga sebagai rumah itu? Apakah rumah itu adalah tempat atau suatu keberadaan (state)? Banyak teolog beranggapan itu adalah suatu keberadaan dan bukan lokasi khusus, karena memang Allah adalah Roh (Yoh. 4:24) dan Tuhan tidak bisa ditaruh dalam suatu lokasi. Namun pada sisi lain penggambaran rumah di surga untuk tubuh kemuliaan dibahas di dalam Alkitab. Doa Bapa kami pun menegaskan tentang: "Karena itu berdoalah demikian: Bapa kami yang di surga, Dikuduskanlah nama-Mu, datanglah Kerajaan-Mu, jadilah kehendak-Mu di bumi seperti di surga“ (Mat. 6:9-10). Untuk memberikan solusi atas hal ini, maka Millard Erickson mencoba memberikan jawabannya bahwa "surga adalah suatu realitas karena surga adalah utamanya keberadaan dan baru suatu tempat, di mana kekhususan dari "rumah" itu adalah pada kondisi keberkatan, tanpa dosa, sukacita dan damai." Penulis sendiri tidak terlalu menyetujui pandangan soal keberadaan (state) karena kehadiran Tuhan itu menyatakan adanya tempat. Surga adalah tempat dan bukan keberadaan pikiran. ${ }^{8}$

\section{Surga itu di mana Yesus Berada}

Walaupun demikian pertanyaan tentang lokasi surga dan di mana lokasinya di alam semesta ini masih terus dipertanyakan tanpa habisnya. Gambaran surga di atas atau di langit masih belum menjawab pertanyaan soal di mana lokasi surga dalam alam semesta ini. Apalagi dengan teknologi saat ini menyebabkan manusia merasa

\footnotetext{
${ }^{7}$ Gagasan ini dikembangkan Erickson, Christian Theology, halaman 1231-2. Ia mengkombinasi antara tempat dan keberadaan (state).

${ }^{8}$ Saya lebih mengikuti pandangan Wayne Grudem, Systematic Theology:An Introduction to Biblical Doctrine (Michigan, Zondervan, 1994), 1159.
} 
sudah menguasai susunan alam semesta ini, sehingga lokasi surga dipertanyakan keberadaannya. Bahkan teolog Kristen sendiri pun sudah ada yang berani meninggalkan konsep surga sebagai tempat dan hanya keberadaaan yaitu kehadiran Tuhan tanpa menyinggung soal tempat. ${ }^{9}$

Maka untuk menjawab pertanyaan lokasi, kita dapat menjawab lokasi surga itu adalah di mana Tuhan bersemayam. Atau dengan kata lain di mana Yesus berada, itulah surga. Boice berkata: "Surga adalah di mana Allah berada. Surga adalah kehadiran-Nya (dan bukan banyaknya yang tinggi dari jalan-jalan emas atau permata-permata) yang menjadikan itu surga." ${ }^{.10}$ Pernyataan Yesus bahwa Ia pergi ke rumah Bapa merupakan penghiburan bahwa mereka dan orang yang percaya kepada Yesus akan bersama-sama dengan Yesus di rumah Bapa yaitu surga.

\section{Surga itu Perjumpaan Orang-orang Beriman}

Hal yang sering ditanyakan juga adalah apakah kita akan saling mengenal di surga. Tentu pertanyaan itu penting mengingat seringnya disebutkan, kita akan berjumpa Tuhan muka dengan muka. Yang jelas, walaupun di dalam surga tidak ada pesta makanan secara harfiah dan kawin mengawin, tetapi semua orang dapat saling mengenal. Meskipun di dalam surga hanya ada tubuh kemuliaan dari Tuhan dan yang pasti dapat mengenal satu kepada yang lain. Boice menyebut ini sebagai reuni dari orang-orang percaya di surga. ${ }^{11}$ Matius 8:11 tertulis: "Aku berkata kepadamu: Banyak orang akan datang dari Timur dan Barat dan duduk makan bersama-sama dengan Abraham, Ishak dan Yakub di dalam Kerajaan Sorga." Ini adalah gambaran surga yang mana kita akan dibuat bahagia mengenal orangorang di sekitar kita bersama-sama di surga. Namun mungkin juga kita akan kaget orang diharapkan masuk surga justru tidak masuk ke dalamnya.

\section{Surga itu Tempat di mana Kita Menjadi Serupa dengan Dia}

Di surga kita akan melihat Yesus dan dapat mengenal satu dengan lainnya. Tetapi eksistensi manusia di surga bukan seperti manusia di dunia. Manusia di surga memiliki kesempurnaan karena memang di surga akan ada kekekalan yang membuat manusia tidak

\footnotetext{
${ }^{9}$ Salah satunya adalah Donald Guthrie yang memercayai surga hanya keberadaan pikiran (state of mind).

${ }^{10}$ Boice, Dasar-Dasar Iman Kristen, 829

${ }^{11}$ Ibid, 832.
} 
berdosa dan tidak dapat berbuat dosa lagi. Ada suatu kebahagiaan yang tidak terkatakan di dalam surga. ${ }^{12}$ Surga adalah Tempat yang sangat Indah dan Penuh Sukacita
dalam Hadirat Allah ${ }^{13}$

Walaupun masih belum lengkap pandangan soal lokasi surga, maka tidak boleh orang percaya kehilangan perspektif bahwa surga melimpah dengan keindahan dan sukacita. Wahyu 21 dan 22 menggambarkan surga sebagai kota Allah. Surga untuk mempelai perempuan yang memasuki pesta perkawinan Anak Domba Allah. Di surga tidak ada lagi kematian, kesedihan dan air mata. Kota ini memiliki keindahan fisik yang tiada dapat digambarkan dengan katakata. Di kota Allah ini adalah pancaran air kehidupan tanpa harus membayar. Kota Allah ini adalah kota kemuliaan Allah di mana penuh bermandikan cahaya yang terpancar dari permata yaspis. Kota Allah ini tidak ada kejahatan, tidak ada yang kotor bisa masuk dan yang bisa masuk adalah mereka yang terdaftar dalam Buku Kehidupan (Wahyu 21:27). Dan orang percaya akan ikut memerintah (Wahyu 22:5).

Selain adanya keindahan surga itu, ada keindahan lainnya yang tidak dapat dibandingkan yaitu adanya persekutuan orang percaya yang akan dinikmati secara kekal dari segala bangsa dan segala zaman. Keindahan ini melebihi segala keindahan lainnya di mana kehidupan bersama yang saling berbagi. Ini jauh lebih indah daripada tiadanya penderitaan dan pelayanan yang dilakukan di surga. Keindahan tertinggi dan termulia itu adalah persekutuan di dalam kehadiran Allah secara kekal.

Jika dalam Alkitab, baik dalam Perjanjian Lama dan Perjanjian Baru manusia tidak tahan akan kemuliaan Tuhan, maka di surga orang percaya dapat menikmati kuasa dan kesucian Allah, karena manusia sudah masuk kepada kekekalan dan suasana kemuliaan Allah. Ini adalah penggenapan akan nubuatan dari Allah yaitu membawa umat-Nya kepada kemuliaan Tuhan sendiri.

Di surga kita akan melihat Dia muka dengan muka. Melihat wajah Allah berarti umat Allah akan melihat kesempurnaan kasih, damai, sukacita, keadilan dan kebenaran Allah. Bila sifat ini dipelajari

${ }^{12}$ Dalam 1 Yohanes 3:2 dikatakan:“Saudara-saudaraku yang kekasih, sekarang kita adalah anak-anak Allah, tetapi belum nyata apa keadaan kita kelak; akan tetapi kita tahu, bahwa apabila Kristus menyatakan diri-Nya, kita akan menjadi sama seperti Dia, sebab kita akan melihat Dia dalam keadaan-Nya yang sebenarnya." Ayat ini menjelaskan bahwa orang percaya akan sama seperti Dia dan memiliki hubungan yang akrab dengan Dia.

${ }^{13}$ Lihat detail penjelasan oleh Grudem, 1163-1164. 
selama di dunia, maka di surga akan didapat kesempurnaan pengetahuan akan sifat-sifat Allah. Dan dalam perjumpaan dengan Tuhan muka dengan muka membuat kita dipuaskan dan tidak ada yang lain yang dirindukan selain Tuhan sendiri. Bahkan tidak ada keinginan di dunia yang bisa menandingi kepuasan bertemu Tuhan muka dengan muka.

\section{Neraka sebagai Tempat Penghukuman Terakhir}

Sekalipun fokus pembahasan dari tulisan ini tentang surga, adalah tepat untuk membahas neraka sebagai bagian dari penghakiman terakhir. Jika surga adalah tempat yang mulia dan keindahan yang tidak terkatakan, maka neraka adalah "tempat hukuman kekal secara sadar untuk orang jahat (hell is a place of eternal conscious punishment for the wicked). ${ }^{14}$ Saya menyetujui pendapat Grudem bahwa yang masuk neraka akan sadar akan hukuman itu. Ungkapan akan ada ratapan dan kertak gigi (Mat. 25:30) di dalam hukuman kekal itu. Ini mengartikan bahwa apa yang dialami di neraka akan disadari oleh yang menerima hukuman itu. Dan hukuman ini akan bersifat kekal adanya.

Namun ada para teolog mulai meragukan konsep ini. Mereka menolak pandangan ini dan menggantinya dan konsep anihilisme di mana hukuman itu hanya bersifat sementara dan pada akhirnya eksistensi mereka yang di neraka akan terhapus (anihilate). Pandangan ini dianut oleh para teolog seperti Clark Pinnock, Philip E. Hughes, David L. Edwards, John R. W. Stott. Begitu pula pandangan kaum Adventist dan juga beberapa teolog lainnya di dalam sejarah. ${ }^{15}$ Pandangan ini tentu memakai argumen soal pemusnahan orang yang dihukum dan juga tentang sifat kasih Allah yang menganggap bahwa neraka adalah bentuk hukuman sementara saja. Tentu pandangan ini ditolak karena kajian teologis tentang neraka memang menempatkannya dalam konteks kemuliaan Allah. Memang pengajaran ini berat karena pada diri kita ditaruh kasih Allah untuk mengasihi yang terhilang, sehingga berat untuk membayangkan bahwa mereka yang kita kasihi harus masuk neraka. Namun sifat Allah tidak dibatasi pada kasih saja, Allah juga adalah adil. Neraka adalah memenuhi prinsip keadilan Allah dan untuk menyatakan kemuliaan Tuhan.

\footnotetext{
${ }^{14}$ Grudem, 1148.

${ }^{15}$ Lihat penjelasan Grudem di halaman 1149-1153 yang memberikan penjelasan alasan mereka percaya dan bagaimana seharusnya kita merespons teolog Kristen yang menganut anihilisme.
} 
Neraka memberikan implikasi beberapa hal: ${ }^{16}$

Pertama, tentang dosa harus mendapatkan hukuman. Ini adalah berbicara tentang Allah yang adil. Kedua, neraka membuat orang percaya kembali serius memikirkan hidup dan perilaku mereka. Pentingnya menjaga kehidupan syukur dengan etika dan kekudusan. Ketiga, neraka menyebabkan kita sungguh menghargai karya Kristus di dunia ini. Kematian dan kebangkitan-Nya tidak akan berguna bila tidak ada hukuman yang akan diterima orang yang tidak percaya dan hidup dalam kejahatan. Keempat, neraka menghasilkan semangat untuk melakukan penginjilan. Kesadaran akan hal ini membuat gereja semakin mengasihi orang yang belum percaya dan membawanya kepada Kristus. Kelima, kepercayaan akan neraka membuat orang percaya menerima fakta tentang kedaulatan Allah dan tujuan dari kedaulatan itu. Doktrin tentang neraka ini akan mengarahkan kita untuk mengharapkan surga yang mulia.

\section{Surga Tempat yang Paling Dirindukan}

Surga seharusnya menjadi tempat kerinduan semua orang percaya. Karena di dalam surga ada hal-hal indah dan tak terkatakan yang terjadi. Di bagian ini kita mau menjawab pertanyaan yaitu apakah kegiatan di surga dan bagaimana menghadirkan surga di dalam pelayanan sebelum memasuki surga itu sendiri:

\section{Kegiatan di Surga}

Menurut Erickson ada aktivitas di surga yaitu berhenti (rest), penyembahan (worship) dan pelayanan (service). ${ }^{17}$ Dalam Ibrani 4:9 dikatakan: "Jadi masih tersedia suatu hari perhentian, hari ketujuh, bagi umat Allah. Sebab barangsiapa telah masuk ke tempat perhentian-Nya, ia sendiri telah berhenti dari segala pekerjaannya, sama seperti Allah berhenti dari pekerjaan-Nya." Kata "berhenti" dan "perhentian" atau "istirahat" tidak dimaksudkan sebagai berhenti dari kegiatan. Itu bukan berarti manusia tidak buat apa-apa padahal dalam desain Allah manusia itu bekerja dan melayani. Kitab Ibrani menggambarkan bahwa masuk ke tempat perhentian seperti Sabat atau memasuki masa perhentian yaitu "berhenti" atau "beristirahat." Kata ini menunjuk bahwa tiada dosa lagi yang dapat mengganggu dan menggoda kita. Tidak ada lagi kesedihan dan penderitaan, juga tidak ada lagi tangis dan air mata. Dalam tugas penyembahan dan pelayanan yang dilakukan akan membuat kita bahagia dan tidak akan pernah melelahkan. Wahyu 21:4 berkata: "Dan Ia akan menghapus segala air

\footnotetext{
${ }^{16}$ Bandingkan dengan penjelasan Donelly, 48-63.
}

${ }^{17}$ Erickson, 1229-1231. 
mata dari mata mereka, dan maut tidak akan ada lagi; tidak akan ada lagi perkabungan, atau ratap tangis, atau dukacita, sebab segala sesuatu yang lama itu telah berlalu."

Kegiatan lain di surga adalah penyembahan dan sekaligus pelayanan kepada Allah. Wahyu 22:3 dikatakan: "Maka tidak akan ada lagi laknat. Takhta Allah dan takhta Anak Domba akan ada di dalamnya dan hamba-hamba-Nya akan beribadah kepada-Nya." Di sini manusia dan segala makhluk di surga akan memuji dan menyembah Dia. Di dalam surga akan terjadi kesempurnaan penyembahan dan manusia melayani Dia. ${ }^{18}$

Penyembahan di surga seperti yang dinyatakan di kitab Wahyu adalah penyembahan yang sangat dalam karena si penyembah memiliki pengetahuan yang dalam tentang Tuhan. Dalam kekekalan ini terlihat kemuliaan yang tidak ada batasnya (infinite), kesucian, kuasa, anugerah kasih karunia, dan cinta kasih. Kesukaan yang tiada taranya (fullness of joy) akan memenuhi hati kita ketika terus-menerus umat-Nya menyembah dan melayani Dia. Pada waktu itu kita tidak akan pernah lagi kehilangan keajaiban kemuliaan-Nya, kasih dan pujian kepada Tuhan.

Implikasi penyataan pelayanan penyembahan yang kita akan lakukan di surga membuat gereja dan orang percaya memerhatikan pelayanan penyembahan dalam gereja. Kita harus meminta kuasa Roh Kudus menuntun kita meningkatkan pelayanan penyembahan dalam gereja, di mana umat Allah harus mempraktikkan penyembahan yang terbaik saat ini sebelum memasuki masa kekekalan itu.

${ }^{18}$ Kitab Wahyu 5:9-13 menggambarkan penyembahan dan pelayanan yang dilakukan di surga: "Dan mereka menyanyikan suatu nyanyian baru katanya: "Engkau layak menerima gulungan kitab itu dan membuka meterai-meterainya; karena Engkau telah disembelih dan dengan darah-Mu Engkau telah membeli mereka bagi Allah dari tiap-tiap suku dan bahasa dan kaum dan bangsa. Dan Engkau telah membuat mereka menjadi suatu kerajaan, dan menjadi imam-imam bagi Allah kita, dan mereka akan memerintah sebagai raja di bumi." Maka aku melihat dan mendengar suara banyak malaikat sekeliling takhta, makhluk-makhluk dan tua-tua itu; jumlah mereka berlaksa-laksa dan beribu-ribu laksa, katanya dengan suara nyaring: "Anak Domba yang disembelih itu layak untuk menerima kuasa, dan kekayaan, dan hikmat, dan kekuatan, dan hormat, dan kemuliaan, dan puji-pujian!" Dan aku mendengar semua makhluk yang di surga dan yang di bumi dan yang di bawah bumi dan yang di laut dan semua yang ada di dalamnya, berkata: "Bagi Dia yang duduk di atas takhta dan bagi Anak Domba, adalah puji-pujian dan hormat dan kemuliaan dan kuasa sampai selama-lamanya! 


\section{Menghadirkan Surga di Dunia Ini}

Surga adalah sebuah kemuliaan dan keindahan yang tiada taranya. Maka itu menantang gereja untuk membawa tugas mulia yaitu misi di mana tugas membawa Injil kepada segala bangsa sehingga mereka mendapatkan kepastian surga. Paulus memberikan contoh tantangan penginjilan, di mana pelayanan misi kita di dunia ini akan membawa kita kepada pertanggungjawaban di takhta pengadilan Tuhan. ${ }^{19}$ Robert E. Coleman berkata: "The Gospel begins and ends in heaven (Injil dimulai dan diakhiri di surga)." ${ }^{20}$ Jadi tanda kedatangan Tuhan pun ditandai dengan Injil diberitakan ke seluruh dunia baru tiba kepada kesudahan yaitu Tuhan Yesus datang untuk kedua kalinya (Mat. 24:14).

Itu sebabnya peran gereja dalam tugas penginjilan adalah sangat signifikan karena populasi surga bertambah dan Yesus akan mengumpulkan tuaian itu pada kekekalan (Yoh. 4:36). Maka tugas menghadirkan surga di dalam gereja ditandai dengan keyakinan yang teguh dari setiap orang percaya bahwa mereka harus memproklamasikan Injil. Ini tugas wajib bagi setiap orang percaya, karena yang tidak percaya Yesus akan kehilangan kesempatan ke surga. ${ }^{21}$ Menghadirkan surga di dunia ini juga dengan kehidupan yang saling mengasihi. Di surga ada kehidupan di mana setiap orang percaya berkumpul dalam kesukaan yang penuh dan kasih yang tiada taranya. Di surga orang percaya akan mengasihi secara sempurna dan tidak berkesudahan. Maka tugas gereja yang tidak kalah pentingnya adalah menghadirkan kehidupan yang mengasihi. Di gereja sepatutnya tidak ada pertengkaran, kesalahpahaman, gosip, roh kritik yang menghancurkan, roh pemecah, dan saling menjatuhkan. Richard Baxter pernah mengeluhkan bahwa "Tidak cukupkah dunia menganiaya orang percaya? Mengapa harus ditambah dengan konflik di dalam kehidupan orang percaya? Mungkin apakah lebih baik jika datang penganiayaan supaya orang percaya bisa kembali saling bersatu dalam mengasihi?"22

${ }^{19}$ Ia berkata dalam 1 Tesalonika 2:19: "Sebab siapakah pengharapan kami atau sukacita kami atau mahkota kemegahan kami di hadapan Yesus, Tuhan kita, pada waktu kedatangan-Nya, kalau bukan kamu?" Jelas sekali Injil adalah bagian penting di surga.

${ }^{20}$ Robert E. Coleman, The Heart of the Gospel (Grand Rapids, MI: Baker, 2011). 261.

${ }^{21}$ Roma 10:14 mengingatkan: "Tetapi bagaimana mereka dapat berseru kepadaNya, jika mereka tidak percaya kepada Dia? Bagaimana mereka dapat percaya kepada Dia, jika mereka tidak mendengar tentang Dia. Bagaimana mereka mendengar tentang Dia, jika tidak ada yang memberitakan-Nya?"

${ }^{22}$ Donelly, 121. 
Hal terakhir yang menjadi catatan tentang menghadirkan surga di dalam dunia ini adalah pentingnya untuk mengukur kehidupan saat ini dengan nilai-nilai kekekalan. ${ }^{23}$ Dunia yang telah jatuh ke dalam dosa tentu punya nilainya sendiri. Nilai-nilai itu mudah masuk ke dalam pengajaran gereja, sehingga tidak heran begitu banyak penyimpangan dan kehancuran yang dialami oleh gereja. Sedangkan surga memiliki nilai-nilai tersendiri tentang apakah yang penting dalam kehidupan. Yesus memberikan nilai surga kepada muridmurid-Nya tentang bekerja di dalam waktu singkat yang Tuhan berikan kepada kita. Ia berkata: "Tetapi kumpulkanlah bagimu harta di surga; di surga ngengat dan karat tidak merusakkannya dan pencuri tidak membongkar serta mencurinya" (Mat. 6:20). Jika gereja menghayati apa yang Yesus katakan, maka cara orang percaya pasti berbeda menginvestasikan hidupnya. Injil dan nilai-nilai surgawi harus menjadi investasi utama dalam kehidupannya. Bila doa mentor saya waktu remaja dulu tentang kesiapan masuk ke surga setiap saat, maka itu akan mengubah perilaku orang percaya untuk mendekorasi hidupnya dengan kesucian, menginvestasikan waktu, tenaga dan uang untuk pelayanan serta membuat penyembahan dalam gereja sebuah persembahan yang indah dan berbau harum di hadapan Tuhan. Tiada lagi waktu untuk mementingkan diri sendiri, dosa dan kehidupan berorientasi menjadi kehidupan yang berbagi bagi sesama dan menghadirkan surga di dalam gereja dan masyarakat. Surga telah memanggil kita untuk membagikan rahasia surga itu kepada dunia sehingga bisa merasakan surga sebelum menuju ke surga yang sesungguhnya.

\section{Kepustakaan}

Boice, James Montgomery. Dasar-Dasar Iman Kristen. Surabaya:

Penerbit Momentum, 2011.

Coleman, Robert E. The Heart of the Gospel. Grand Rapids, MI: Baker, 2011.

Donelly, Edward. Biblical Teaching on the Doctrines of Heaven and Hell. Edinburgh, UK: Banner of Truth Trust, 2005.

Erickson, Millard J. Christian Theology. USA: Baker, 1995.

Grudem, Wayne. Systematic Theology:An Introduction to Biblical Doctrine. Michigan, Zondervan, 1994.

Lewis, Rodger. Karya Kristus di Indonesia. Bandung: Kalam Hidup, 1995.

\footnotetext{
${ }^{23}$ Coleman, The Heart of the Gospel, 262.
} 